\title{
The impersonalisation of God? A theological analysis of the expression of the power of God's kingdom among Zimbabwean Pentecostal prophets
}

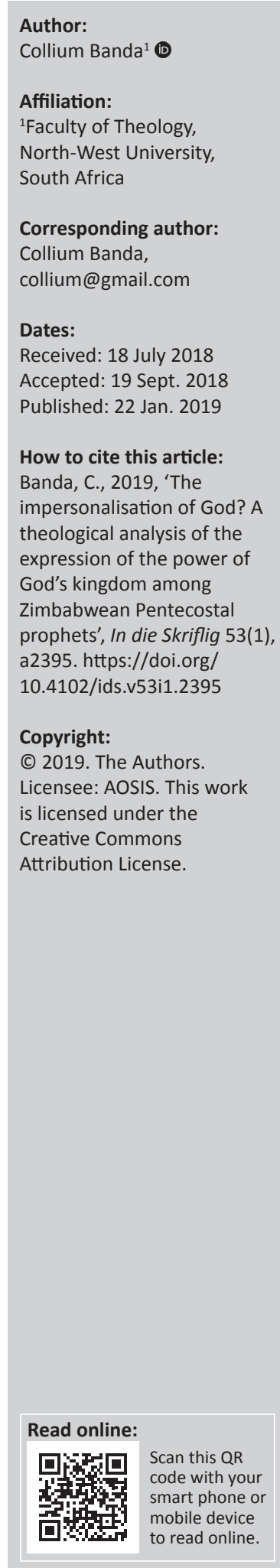

How can the expression of the power of God's kingdom in the ministry and teaching of some Zimbabwean Pentecostal prophets be evaluated from the doctrinal perspective of the personality of God? The article analyses the expression of the power of God's kingdom among some Zimbabwean Pentecostal prophets from the perspective of the doctrine of the personality of God. The article observes that, although Pentecostal prophets in Zimbabwe claim to be empowered by the kingdom of God, they tend, nonetheless, to project an impersonalised view of the power at work in the kingdom. It is argued that the impersonalisation of the power of God leads the prophets to commodify the kingdom into something that can be controlled by a person's religiosity. Consequently, the article describes the Pentecostal prophets' understanding of themselves as special agents of God's kingdom. It further argues that the impersonalisation of the power of God's kingdom leads the Pentecostal prophets in commodifying the kingdom of God by reducing it to something that can only be accessed through them. The article closes by examining how a biblically derived understanding of the personality of the God of the kingdom can assist in discouraging the common impersonalisation of the power of God's kingdom among some Zimbabwean Pentecostal prophets.

\section{Introduction}

Pentecostal prophets explicitly and implicitly present themselves and their ministries as driven and sustained by the power of God's kingdom. The prophets constantly challenge their followers to ensure that they live within the kingdom of God. As an example, one of Zimbabwe's leading Pentecostal prophets, Walter Magaya (2015a), says:

The Kingdom of Heaven then is the throne of God. The Throne of God is fullness of life i.e. joy, peace, love and whatever you aspire to have on earth. If one gains the Kingdom of Heaven they have fullness of life. If you want to know if you are truly in the Kingdom of God you have to have the fullness of life. If you want to know if you are in the Kingdom of God, it is seen by the fullness of life. (n.p.)

Magaya emphasises the need for Christians to gain the kingdom of God, and provides them with a checklist by which they can evaluate their true standing within the kingdom of God. It is in light of this explicitly stated importance of God's kingdom by Magaya and other like-minded Pentecostal prophets that this article interrogates the Pentecostal prophet's understanding of the power at work in the kingdom of God.

The main question of the article is: What is the understanding of the nature of the power that works in the kingdom of God as expressed in the Zimbabwean Pentecostal prophets' preaching and teaching about the manifestation of the kingdom? How can the doctrine of God assist in addressing the shortcomings in the Pentecostal prophets' view of the power of God's kingdom? The article begins by describing how Pentecostal prophets understand themselves as special agents of God's kingdom. The following section highlights the problem of the prophets impersonalising the power of God's kingdom, resulting in relating to God in magical terms instead of personal relational submission. The next section shows that the impersonalisation of the power of God's kingdom among Pentecostal prophets has led to the commodification thereof by reducing it to something that can only be accessed through the prophets. Consequently, this has undermined the role of the gospel in leading people to the kingdom of God. The article closes by examining how a soundly biblically informed understanding of the personality of the God of the kingdom can assist in discouraging the common impersonalisation of the power of God's kingdom among some Zimbabwean Pentecostal prophets. Discussion of the various complex debates on the kingdom of God fall outside the focus of this article (Ladd 1993:54-67; 
2001:657-661; Seccombe 2002:166-199). The article will limit itself to the theological question of the nature of the power at work in the kingdom of God.

\section{Pentecostal prophets as special agents of God's kingdom}

Zimbabwean Pentecostal prophets present themselves and their ministries as driven by the kingdom of God and pursuing its agenda in this world. The names of some prophetic ministries, for example Prophet Passion Java's Kingdom Embassy, clearly indicate their orientation regarding the kingdom of God. Whereas Walter Magaya's Prophetic Healing and Deliverance (PHD) ministries does not bear 'kingdom' in its name, its link to the kingdom is demonstrated by the emphasis on healing and delivering people from demons and diseases which characterised Christ's demonstration of the arrival of the kingdom in the world. Magaya (2015b) presents himself as preaching God's word that demonstrates 'God's Power and that power resembles God's Kingdom here on earth [sic]'. This shows that he acts under the serious conviction that he is God's special agent of the kingdom and therefore is unquestionably fully endowed with God's unique calling and anointing.

Prophet Emmanuel Makandiwa's United Family International Church (UFIC) has a church journal called The Family, reporting on his various prophetic activities. In a report entitled 'Soul Winning Crusades Filled with Miracles, Signs and Wonders' in The Family (2014a:32-33), describes Makandiwa ministering with 'rare spiritual brilliance', 'overshadowed by the power of God' and in 'an atmosphere of the awesome presence of God's glory and power descended'. The narration deliberately distinguishes Makandiwa's prophetic activities as uniquely manifesting the power of God's kingdom. Makandiwa (The Family 2014a:33) calls people 'to come to the Kingdom of God where Jesus would lead them to the perfect plan of God for their lives'. In prosperity Pentecostalism, God's perfect plan for people's lives includes living a prosperous life; hence, Makandiwa (2017) expresses the power of God's kingdom by healing and delivering people from sickness and demon possession. The above-noted reports from The Family present Makandiwa as fully adhering to the pattern set by Christ in the gospels of demonstrating the arrival of the kingdom through preaching and miracles.

Prophet Walter Magaya (2015b) declares, 'All the terminology in the bible [sic] speaks about Kingdom.' Magaya sees the thrust of the entire biblical message as spreading and establishing the kingdom of God on earth. In Magaya's understanding (2015b):

The whole idea of the Holy Bible is to colonise - where to colonise is whereby one kingdom extends its territory to another territory ... [Therefore], the bible [sic] is about Heaven Kingdom colonising Earth. (n.p.)

To this end, a colonised territory must change its culture and adopt the culture of its coloniser (Magaya 2015b). Magaya (2015a; 2015b) sees the kingdom of God and the kingdom of heaven as synonymously referring to 'the throne of God'. In other words, those who have been colonised by the kingdom of heaven must adopt its culture and demonstrate it in their lives. Consequently, the establishment of the reign of God must be reflected on earth, its colony. However, in prophetic Pentecostalism, although Christ-like holiness is certainly in focus, the emphasised and distinguishing characteristic of adopting the culture of heaven is material prosperity and physical well-being. As Magaya (2015b) states, 'The Kingdom is all about good health, peace, prosperity and no sorrow.' Consequently, Magaya (2015b) expresses dismay that, whereas Jesus brought on earth the heavenly culture of good health, peace, prosperity and no sorrow, some church ministers resist the glorious heavenly culture and push it back to heaven by teaching that prosperity will only be experienced in heaven, and suffering and poverty must be accepted on earth. He condemns such teaching that actively resists heavenly colonisation as being here[tically] ... busy preaching doom' (Magaya 2015b). In the statement, Magaya expresses an over-realised eschatology that holds to the complete manifestation of God's kingdom in present existence through a perfect life. He (Magaya 2015b) assertively states:

The reason why sickness, poverty and sorrow are ruling here on earth is because very few of us believe that the Kingdom of heaven is and must be here on earth. If many of us could speak with the same voice and belief that the Kingdom of God has come here on earth, 'Thy Kingdom come'. All evil spirits would flee from our lives, the devil would lose control of this world. Man [sic] was given dominion over earth but it is our religious beliefs that have handed power and our dominion over to the devil, Satan. (n.p.)

The lengthy quote brings out the full extent of Magaya's conviction that he is an agent of God's kingdom and the objective of his ministerial activities is the manifestation of the full kingdom in this present life. On another occasion, Magaya (2015a) categorically states:

If one gains the Kingdom of Heaven they have fullness of life. If you want to know if you are truly in the Kingdom of God you have to have the fullness of life. If you want to know if you are in the Kingdom of God it is seen by the fullness of life. (n.p.)

This fullness of life, wrought by the kingdom of God, is demonstrated by a flourishing life. To express his conviction that people must experience the fruits of God's kingdom in this present earthly life, Magaya (2015b) states:

The Kingdom of heaven must start here on earth. The Kingdom is all about good health, peace, prosperity and no sorrow. How can you manage in the heavenly Kingdom when you haven't exercised that life here on earth? (n.p.)

Magaya's question of how Christians can expect to manage prosperity in the heavenly kingdom when they have not exercised the heavenly life here on earth conveys his conviction that a glorious life of material plenty indicates the real presence of God. It is the evidence of having the kingdom of God. Another implication from Magaya's question is that, 
experiencing prosperity in this life, prepares one for future management of a prosperous life in heaven. This means that those who resist prosperity here on earth may be disqualifying themselves from attaining a life of material prosperity in future heaven

Makandiwa (2014:7) concurs with Magaya by asserting that kingdom living leads the believer to be 'above every principality, every power, every rulership of the darkness of this world and every spiritual wickedness in high places'. Makandiwa reportedly demonstrated the comprehensive breadth of the power of God's kingdom by concluding his sermon on the power of God by inviting people with sleeping disorders to come to the front stage and commanded them to fall asleep and many of them instantly fell into a deep sleep (The Family 2014b:11). Such miraculous acts, which lead to human flourishing, demonstrate the outworking of the power of God's kingdom.

It is beyond the purpose of this section to analyse the Pentecostal prophet's overly functional and materialistically this-world view of God's kingdom, but to only highlight the heightened consciousness of being agents thereof. Balcomb (2007:32) notes, with reference to the New Charismatics (neoPentecostals) into which African Pentecostal prophets fit, that the notion of God's kingdom is 'usually termed "the Kingdom", which has to do with a strong emphasis on the present not the future, and values the idea of engagement with the world'. In the above-noted scenarios, the Pentecostal prophets emphasise the full, active presence of God's kingdom that challenges and transforms people's existential situations. Hellstern (1989:80) comments that a leading American prosperity preacher of the former generation, Charles Capps, once stated, 'You can have the kingdom, and the benefits right here on earth.' This is tantamount to subscribing to a form of over-realised eschatology that views the kingdom of God as already fully existing in the present world. Therefore, the responsibility of Christians is to begin to demand back from Satan the good things of life (particularly money), and to begin to live on this earth as the 'King's kids' (Hellstern 1989:80). The Pentecostal prophets act out of their conviction of being the agents of God's kingdom. Their prophetic activities function as manifestations of the active presence of God's kingdom.

\section{Theological problems in the Pentecostal prophetic view of God's kingdom}

Although the African Pentecostal prophets' view of God's kingdom can be evaluated from several perspectives, this article is concerned with the perspective of God that informs their notion of the kingdom. This section will contend that Pentecostal prophets tend to project a view of the kingdom that is less informed by God's divine personhood. That leaves the prophets to view the kingdom in terms of wonder working power that can only be manipulated by those (such as the prophets) who have mastered the necessary skill to attain it. The impersonalisation of the kingdom ultimately leaves Christians more dependent on the prophets to access the power of the kingdom instead of relating to the God of the kingdom. The following analysis of the impersonalisation of God's kingdom among Zimbabwean Pentecostal prophets is alert to the point raised by John de Gruchy (1979:195-237) that various Christians have employed the image of God's kingdom in their socio-political and economic agendas.

\section{The emerging impersonal view of the power of God's kingdom}

Listening to the Pentecostal prophets' view of the power of God's kingdom, the question that emerges is: What is the nature of the power that works out the miraculous in the kingdom of God as projected by the African Pentecostal prophets? Pentecostal prophets are vulnerable to the charge of depicting the power at work in the kingdom of God as an impersonal power - almost in magical terms - instead of the power of the personal, independent and sovereign God. For example, in a sermon on the kingdom of God, Prophet Emmanuel Makandiwa (2013) proclaimed:

Every time you step into a kingdom you see power at work. And how do you see power at work? You see commands proceeding from the mouth of the king. And servants are ready to take orders. As the king is sitting like this, he says this and they are running [sic]. So when you want to demonstrate the kingdom of God as a child of God, you open your mouth and you realise words. You can send a word on assignment to go out there and find you what you are looking for. I might not know, and I don't even know how I will get there, but since I have released a word, I have employed the word to go out there and work for me. As to when the money is going to come, I don't know; but all I know is that I have spoken the word - I am a millionaire, I have spoken it. (n.p., [author's own italics])

Makandiwa's teaching of employing the word to accomplish things on one's behalf has a long history which is beyond tracing in this article. Notable historical figures on the art of positive confession include individuals such as Esek William Kenyon, Kenneth Hagin and Charles Capps. Another popular figure, Pastor Chris Oyakhilome (2007:30), says:

What do you want? What do you want your world to look like? How do you want your home to be? Begin to paint the picture in your mind and brood over it; let it fill your mind, and allow the Holy Spirit to aid you, by vitalizing your imagination with declarations from God's Word concerning you. And soon, just like at the creation, you will speak it into being. (pp. 22-23)

He (Oyakhilome 2007:30) further adds the following: 'So start sowing the right seeds and keep watering them with your confessions and you will surely reap the right fruits.' Makandiwa (2013) charges the congregants of the need to 'correct your mouth, and get you to say the right things'. From this view, the kingdom of God is not related to as something belonging to a personal deity, but to an impersonal force or system that can be controlled by the power of one's confession which seems to thrive on either the magical manipulation of words or the magical manipulation of God. 
Rather, the dependence on God that emerges is dependent on the art of confession. Hellstern (1989:81) highlights Charles Capps announcing $=$ that 'YOU CAN HAVE WHAT YOU SAY' [Hellstern's capitalisation] to emphasise the believers' responsibility to alter their affairs by their own positive speech. Therefore, for Pentecostal prosperity preachers, 'it is ultimately the responsibility of the individual believer to believe - to have faith in his faith - to claim God's promises' (Hellstern 1989:89). Magezi and Manzanga (2016:4) highlight Hagin's belief that Christians ought to act like God who had faith in his faith and decreed things into being. However, this does not nurture a faith that relies on God, but a faith that thrives on the person's power, resulting in self-determinism and self-dependence. Rather than focusing, relating and depending on God, the projected faith is human centred by believing in the power of one's art of incantation. As Hellstern (1989:89) highlights, faith teachers promote the idea that 'a Christian's perfection is already available if one would learn merely to claim it'. Therefore, instead of depending on God, the Christians end up depending on themselves.

Consequently, instead of God being treated as a personal being to be personally related with and to be prayed to, because he is independent and has sovereign will, God ends up superstitiously treated as 'the Lord of magic, and Himself subject to its influence' (Nyamiti 1997:58). This is affirmed by the growing use of the anointed objects of the Pentecostal prophets such as anointed oil and anointed water. The anointed objects reflect a deistic view of an absent God who has left the world to work on its own and therefore he is unreachable for human beings so that they have to resort to magical schemes to reach and relate to him. Although some may view such objects to actually objectify God's presence to make it 'visible', the problem is that the anointed objects undermine direct personal faith in God. Furthermore, the selling of the anointed objects distorts the biblical idea that God is graciously available to all who pray to him in faith. This Pentecostal prophets' impersonalisation of God fuels the African traditional religious (ATR) understanding of God as unapproachable by human beings and therefore people have to rely on ancestors and magical instruments. The Pentecostal prophets' impersonalised form of the God of the kingdom is contrary to the personal God illustrated in the Bible in texts such as the Lord's Prayer (Mt 6:9-13) where God is presented as a relational being with his own sovereign will.

\section{The sacralisation of the personal being of the prophet}

Linked to the impersonalisation of the God of the kingdom, is the sacralisation of the prophets and granting them quasidivine status. Magaya (2015b) states, 'We are kings and priests, and our children are the princes and princesses. We are led by the King of kings of which we are the kings.' The idea is that Christian conversion transforms believers into children of God the King, making them princes and princesses. The problem in Magaya's view is that being the princes and princesses does not mean that we have the authority of the King. Magaya further understands Christ's designation as King of kings to mean that his followers become kings under Christ, and so he fails to understand that the designation affirms Christ's supremacy over all authorities. However, at the centre of Magaya's view is the principle of deification that makes Christians little gods. Older fathers of neo-Pentecostalism held this view. Morris Cerullo is highlighted by Magezi and Manzanga (2016), declaring on the basis of Genesis 2:7:

Did you know that, from the beginning of time, the whole purpose of God was to reproduce Himself? Who are you? Come on, who are you? Come on, say it: 'sons of God'. Come on, say it ... And as we stand up here, brother, you are not looking at Morris Cerullo, you are looking at God. You are looking at Jesus. (p. 5)

This deification of Christians as 'little gods' is constructed from a particular reading of texts such as Psalm 82:6 and John 10:34-35. While it may appear that all Christians can claim to be little gods, yet, in African Pentecostalism, there is a hierarchical order that propels prophets and pastors to a higher status, giving them the exclusive claim to the title 'Men of God' or 'Women of God' (Gunda \& Machingura 2013:17). For instance, Takura Rukwati (2012), a faithful follower of Prophet Emmanuel Makandiwa, describes him as one who sits in the council of God and functions as the eyes and mind of God and thus 'there is always a violent reaction from the heavens when his prophets are touched, embarrassed, harassed, persecuted or killed'. Therefore, to Rukwati (2012), ' $[t]$ ouching a prophet is a short cut to the grave according to Psalms 105:14-15, graves of sicknesses, poverty, misfortunes, even spiritual and physical death'. Consequently, resisting and questioning their wishes, needs and decisions is tantamount to opposing and questioning the kingdom of God.

To affirm his own self-sacralisation, Angel (2013) teaches that it is giving to the anointed Man of God - not the church - that leads to the quickest blessed way to acquiring riches. ${ }^{1} \mathrm{He}$ (Angel 2013) charges the believer who seeks wealth to first:

understand that there are men of God who are good ground for every seed. When you find them they will be able to sustain every seed sown by their anointing. These are Men of God with great anointing and you don't have to guess who they are. Look at their substance. What do they have? Do they have plenty or less? What achievements do they possess? What is the impact they have made on earth? (pp. 86-87)

This statement sacralises human beings as channels of access to the blessings of God's kingdom. Considering Magaya's above-noted emphasis that Christians should enjoy the full benefits of God's kingdom in their earthly existence - to then be told by Angel that one must give money to anointed prophets to be rich - removes all direct dependence from God and places it on the 'anointed' people. In traditional Christianity, giving to the church and charity are considered

1.Such new teaching in neo-Pentecostalism is not surprising, for Hellstern (1989:81) shows that almost all the older generation of the health and wealth teachers shows that almost all the older generation of the health and wealth teachers
'claim[ed] to have received fresh, post-canonical revelation, in which God reveals particular new truths or hidden meanings behind Old or New Testament Scriptures'. 
acts of giving towards the kingdom of God and therefore are highly blessed acts. Nevertheless, Angel (2013) invalidates such giving by teaching that, before giving:

[Y]ou need to keep in mind that if someone doesn't have the ability to buy a car it would be very reasonable to know it's very stupid to try and sow into them expecting a car that they as your soil have no potential to bring into manifestation. That will be sowing into the wind. You reap nothing! (pp. 90-91)

By this statement, Angel contradicts several biblical teachings on the biblical priority of giving to the poor and the blessedness of generosity towards the poor (e.g. Pr 22:9; Ac 20:34-35; 2 Cor 9:6-11). He bizarrely teaches a form of giving to rich prophets for their self-gratification as a means to blessedness by God. It further contradicts the example set by God when he generously gave his only Son to die on the cross to save poor and desperate human beings who could never be of material benefit to him (2 Cor 8:9). Moreover, the whole scheme sacralises the prophets by giving them the power to bless those who give to them generously and (by default) even to curse people who withhold their money from them. In this scheme of things, the prophet's happiness translates into blessedness to the givers. ${ }^{2}$ In this scheme of things, rather than receiving the blessings of the kingdom by serving God, the prophets also function as alternative channels of receiving the blessings of God's kingdom.

From the perspective of God's kingdom, it seems that when the God of the kingdom is impersonalised and turned into a power that can be magically manipulated, it allows the sacralisation of the prophets to thrive unhindered. The sacralisation of the Pentecostal prophets thrives on the impersonalisation of God or the creation of a chasm between the believers and God, and then places themselves as the only effective links between God and humanity.

\section{The replacing of submission to the Lordship of Christ with pursuing materialism}

Related to the above points, the impersonalisation of the God of the kingdom replaces surrender to the Lordship of Christ by the unchecked pursuing of materialism. The impersonalisation of God by African Pentecostal prophets promotes a form of Christian discipleship and spirituality that is shaped by worldly consumerism rather than surrendering to the Lordship of Christ. Balcomb (2007) suggests that:

In spite of the motif of surrender of the self to the Lordship of Christ, there is little or no inclination towards an ethos of selfdenial or suffering for the sake of the Kingdom of God. (p. 41, [Balcomb's italics])

\section{The problem lies in that the:}

message and social ethos of the Pentecostals coincides with what could be referred to as the Zeitgeist of the advancement of the self, including the values emphasised in a modern consumerist capitalist society. (Balcomb 2007:40-41)

2.This resembles ancestor veneration in African traditional religions who, when they are appeased by gifts, realise blessings on their worshippers.
The resultant picture of God's kingdom is one of materialistic consumerism instead of the virtues of righteousness, justice and holiness. Rather than voices of holiness, righteousness and justice, and a voice of conscience of the society, the image of the prophets is increasingly that of glamorous wealthy businessmen who flaunt their wealth (Bulawayo24News 2013; Forbes Africa 2014; Mahohoma 2017; Marshall 2009; Nehanda Radio 2018).

As a result of preoccupation with materialism, some of Zimbabwe's leading Pentecostal prophets have reportedly been taken to court on charges of fraud (Chitemba 2017; Nemukuyu 2014). Not only does this discredit the kingdom of God, it also led some people to contemptuously describe African Pentecostal prophets as 'gospelprenuers' (Chitando, Gunda \& Kügler 2013:9). Some Zimbabwean Pentecostal prophets portray an image of God's kingdom riddled with unbridled material greed that lacks the capacity to provide the needed compass of moral justice (Balcomb 2007:41). The lack of political activism may be due to a narrow view of God's kingdom that is preoccupied with the present, and is insufficiently informed by the salt and light in a context of social, political and economic injustice in the country. The prophets' engagement in political activism 'generally tends to support the status quo' (Chitando \& Biri 2016:74). Balcomb (2007:41) highlights that Pentecostal theology differs from Liberation theology by its emphasis that 'is overwhelmingly on the individual and not on society, its structures, or its history'. This lack of political activism may be due to a narrow view of God's kingdom preoccupied with the present, while poorly informed by God's eschatological vision of future 'comprehensive well-being' (Nürnberger 1994:119) the Shalom, of future 'healing and wholeness of human relationships, of the well-being of creation, and of the covenantal between Yahweh and Israel' (De Gruchy 1995:44).

\section{The emergence of a commodified view of God's kingdom}

The contention so far is that Zimbabwean Pentecostal prophets tend to impersonalise the power of God's kingdom by presenting it as a reality that can only be accessed by magical manipulation instead of a personal relationship with the personal God. Indubitably, this leads to a form of commodification of God's kingdom as Pentecostal prophets project an idea of being the exclusive channels into the kingdom.

Chitando and Biri (2016) attempt to project Prophet Walter Magaya as an ecumenist. However, it is a parochial, selective and exclusive ecumenism limited only to like-minded Pentecostal prophets that does not extend to the broad universal church. The lack of ecumenism is seen in Kgatle (2017:2) and Marshall (1992:16) who highlight that NeoPentecostalism thrives on personalities who rebel from their churches to reconstruct a new, fresh and more kingdom-ofGod-oriented faith. ${ }^{3}$ Pentecostal prophets, in line with their

3.From a South African perspective, Kgatle (2017:2) highlights the lack of ecumenism by saying that neo-Pentecostal churches are known for their refusal to affiliate with established denominations. 
view of their ministries as the only anointed ones by God and the only ones led by the Holy Spirit, tend to project themselves to be the ones manifesting the power of God's kingdom. This can be discerned in Magaya's already noted condemnation (2015b) that:

The worst person today is the Pastor or Apostle who is still teaching congregants that we shall rejoice in heaven and we must be ready to suffer here on earth. That's heresy. You are busy preaching doom in those churches right on the altar by the pulpit. Theology has misled Pastors and congregants. (n.p.)

In this statement, anyone holding a different view from the one held by the Pentecostal prophets is considered outside the kingdom of God. Magaya does not seem to be aware of various Christian traditions within the history of the church that meaningfully viewed suffering and sacrifice as a means of experiencing the kingdom of God. Magaya (2015b) condemns what he calls 'religion and theology' and avers that he will not advise anyone to go to a Bible or theological school, because ' $[w]$ rong theories of God's Kingdom are being reinforced in the minds of many people through those colleges'. He (Magaya 2015b) puts his position beyond contestation by the following words quoted at length:

\begin{abstract}
About $97 \%$ of Christians today do not really know the exact position of the Kingdom of heaven. They are still confused and even lost, even though they believe themselves as Christians. No wonder you see or hear some Christians fighting other Christians. How can the same children of God fight one another? Why would one man of God denounce another man of God? All these are true indications of the level of our fellow Christians that they are ruled by religion, not by God's Kingdom. The same $97 \%$ are not true Christians but religious people who are trying to be. They are people who are innocently lost in the search of Christianity through the misleading bible colleges. (n.p.)
\end{abstract}

The idea that it is only 3\% of Christians who really know the exact position of heaven's kingdom and who are true Christians, while the other $97 \%$ wallow in lost confusion, categorically limits the presence and work of God's kingdom to his prophetic ministry and other like-minded Pentecostal prophets. Therefore, those who want to experience the kingdom of God must look only to Magaya and other prophets like him.

A serious problem is that, by exclusively limiting the manifestation of God's kingdom to their ministries, Pentecostal prophets assume a role that turns both the kingdom and their followers to become their personal properties. For example, Maxwell (2006) quotes Ezekiel Guti of the Zimbabwe Assemblies of God in Africa (ZAOGA), warning the church pastors of his church:

If you don't want to die or leave and get poor, or have little kids mock you in the streets, then stay and grow rich. People who have left do not prosper; they lose their blessings. When they get old they have nothing. It takes time to build a church and to start making money. (p. 154)

The statement presents a view of the kingdom's power as exclusively located in his church, and further sets himself as the only avenue through whom the blessings of the kingdom can be accessed. Eventually, he personalises his followers (Magezi \& Banda 2017:2-4). The message is that, without Guti, the followers are doomed. Therefore, the kingdom of God has become a commodity accessed through Guti.

In another example of the commodification of God's kingdom, Makandiwa was reported in the news, telling people who wanted 2017 to be a blessed year to sow seeds (giving of money) in the amounts devisable by the number 7 , but in the ranges of $\$ 77, \$ 770, \$ 7700$ or $\$ 77000$ (The Sunday Mail 2017). The problem is that access to the power of the kingdom is turned into a commodity only accessible to those who give large sums of money to the prophet. The kingdom becomes a commodity that is dispensed under the control of the prophets.

The commodification of God's kingdom is demonstrated by the replacement of the sacraments of the church (particularly baptism and Holy Communion) by 'divine directives' (Kgatle 2017:6) to perform 'unconventional practices' (Resane 2017:1) of distributing anointed mantles (Bulla 2015) and, on some occasions, it has bizarrely included, distributing anointed cucumbers (Chaya 2016) and even anointed condoms (Mbanje 2015). ${ }^{4}$ This perspective, again, reduces the kingdom of God and its power to a commodity that can only be disbursed by the prophets. The tragedy is that the prophets and their unusual practices replace the gospel of Jesus Christ which leads to salvation by faith. Rather than a realm of encountering a relational and loving personal God, the kingdom is reduced to an impersonal realm at the control of the prophets and their anointed objects.

\section{The personality of God in addressing the prophets' impersonalisation of the power of God's kingdom}

This section looks at some aspects that challenge the impersonalisation of the power God's kingdom by Pentecostal prophets. The following points can be used to challenge Pentecostal prophets to break away from impersonalising the power of God's kingdom.

\section{The kingdom as a reality of the personal God}

Within the complex and inconclusive debate on the definition of God's kingdom and whether the kingdom is a realm, reign, community or new age (Seccombe 2002:174-178), there is significant consensus that the kingdom is both present and future (Ladd 1993:56; Seccombe 2002:170). Christ presented the kingdom as already actively present, but awaiting full consummation on his glorious return at the end of time (e.g. Lk 17:20-37). However, one may opt to think of the present nature of the kingdom. A foundational point to be recognised is the following: 'The Kingdom is God's

4.Resane (2017:12,14) controversially highlights that, in many neo-Pentecostal churche, 'sacraments as churches, 'sacraments are replaced with 'divine' directives to shakes and rats, drink petrol, nakedness displays, walking on devotees' bodies, driving cars over devotees' bodies'. In agreement, Kgatle (2017:6) views the unusual practices of the neo-Pentecostals as 'a sign of being antisacramental'. 
Kingdom, not humanity's basilieia tou theou. The emphasis falls on the third word, not the first; it is the Kingdom of God' (Ladd 1993:79). Similarly, Guthrie (1981:419) emphasises 'the theocentric character of the kingdom' [Guthrie's italics]. He (Guthrie 1981:419) further stresses that the theocentric nature of the kingdom 'is of fundamental importance in understanding the mission of Jesus'. Amplifying T.W. Manson, Ladd (1993:79) says it has to be reckoned every time that Christ's conception of God determined everything he taught including his conceptualising of the kingdom and Messiah. This important point emphasises that the kingdom of God, whether in present form or eschatological in nature, is not just a mere good system or principle, but 'the scene of the redemptive acting of God' (Ladd 1993:80). Even in the Old Testament, the expectation of God's kingdom was, above all, not just a hope for restoration, but an expectation that the loving and just God will manifest his personal presence and dwell among his people. This is seen even in John the Baptist, questioning Christ whether he was the expected Messiah to which Christ responded by pointing out the signs of God's activity among his people (Lk 7:18-28). In Jesus' ministerial actions and new teachings on the kingdom, God is revealed in personal terms such as the seeking God, the inviting God, the fatherly God and the judging God (Ladd 1993:79-88). As presented by Jesus, the kingdom of God is not a mere impersonal principle or system, but a reality in which a personal and relational God actively dwells among his people.

Therefore, the Pentecostal prophet's idea of God's kingdom needs to be informed by God's personality. Frame (2002:25) points out that God 'is not ... an impersonal force to be manipulated by human ingenuity'. Among other things, personality means that God 'acts on his own initiative, rather than merely responding to events' (Frame 2002:25). Consequently, he cannot be manipulated by seed offerings no matter how huge. God, the King of the kingdom, is not a mystical power to be mastered, manipulated or appeased such as some form of a mystical life force, vital force or mystical power of good luck. Consequently, there is urgent need amid Pentecostal prophets to realise that the kingdom of God, among other things, is essentially the personal domain of the sovereign God. Therefore, it is he alone, not the prophets, who controls what happens in his kingdom. Accordingly, an important step towards the decommodification of God's kingdom among Pentecostal prophets requires a sound understanding of God's personal nature.

\section{The personal power of God at work in his kingdom}

Affirming the personality of the God of the kingdom further personalises the power at work in the kingdom. This affirms that the 'Kingdom is the outworking of the divine will; it is the act of God himself, Jesus' (Ladd 1993:102). The power at work in the kingdom is the personal divine power of God not some magical or cosmological vital force that can be commodified by certain individuals who have mastered some skills. The recognition of the power at work in the kingdom as the personal power of God derives from a trinitarian view of the kingdom. Jesus exhibited a trinitarian view of the kingdom by projecting the work of the Holy Spirit in his ministry as manifesting the arrival of God's kingdom. For example, the Spirit anointed him for the ministry of God's kingdom (Lk 4:18-21) and he cast out demons by the Holy Spirit (Mt 12. 22-32). In Matthew 12:28, Jesus states that his casting out of the demons by the Holy Spirit signalled the arrival of God's kingdom. Dunn (2011) explains that, in the Greek of Matthew 12:28, the emphasis lies on the first and the last phrases: 'Since it is by the Spirit of God that I cast out demons, then has come upon you the kingdom of God.' Jesus meant that the 'power of the Spirit is the presentness of the kingdom, God's kingly rule already in evidence' (Dunn 2011:107). After his resurrection, Jesus is presented as reigning on the right hand of the Father, but reigning in the believer and also in the church through the Holy Spirit who indwells the believer and the church. Therefore, a crucial element toward a sound grasp of the power of God's kingdom is a sound knowledge of the Trinity, particularly a sound awareness of the personality of the Holy Spirit.

\section{The kingdom as the work of God}

It is significant that Christ emphatically presented the kingdom of God as exclusively the work of God. In John 18:36, Jesus rebuts Pilate by telling him that his (Christ's) kingdom is not of this world, but of another world - otherwise his servants would have fought to prevent his arrest by the Jews. In this statement, Jesus asserts that the kingdom of God is the outworking of the act of God himself. This declaration, when looked at from his other teachings that assert the independence of the kingdom (Mk 4:26-29), shows the personality of the God of the kingdom by affirming him as having his own will, purposes, independence and sovereign control over his kingdom. In Jesus' teaching, God is the one who establishes his kingdom: he gives it to the people (Mt 21:43; Lk 12:32). In essence, it is only the supernatural powerful act of God that can destroy Satan, defeat death (1 Cor 15:26), raise the dead in perfect bodies to receive the blessings of the kingdom (1 Cor 15:50) and transform the world order (Mt 19:28; Ladd 2001:658). However, there are things that people do to the kingdom such as accepting it or rejecting it and people can do certain things for the sake of the kingdom (Mt 19:12; Lk 18:29) such as preach the kingdom (Mt 10:7; Lk 10:9), invite others and even hinder others from entering it. No human being can, however, destroy the kingdom of God; neither do people have the power to give the kingdom to others nor can they do anything to take it away from others. However, 'they are never said to erect it or build it; they are never to establish it; they cannot destroy it' (Ladd 1993:102). Stated plainly, the kingdom of God is exclusively God's divine personal initiative, while fully related to human beings, working in and through them; yet, human beings can never wrestle it away from his control and subject it to themselves (Ladd 1993:102).

\section{Human agency in the kingdom of God}

The assertion of the personal nature of God as a remedy to the impersonalisation of the kingdom's power, leading to 
the commodification of the kingdom among Zimbabwean Pentecostal prophets, leads to the question: If the kingdom of God is exclusively God's work, what then is the relationship between human agency and divine agency in the establishment and growth of God's kingdom? Ladd (2001:658) answers this question by emphasising that the 'kingdom is altogether God's deed although it works in and through humans' [Ladd's italics]. This shows that the kingdom's divine agency employs human agency which means that human effort has an essential role in the establishment and growth of the kingdom. As an example, while Jesus divinely inaugurated the kingdom, he gave the keys of the kingdom to the church (Mt 16:18-19) and also enabled his disciples to preach the kingdom and perform its signs (Mt 10:7-8; Lk 10:9-17). The place of human agency in the kingdom is seen in Horton's analysis (2011) that Acts 2 shows that:

the preaching of the gospel and the administration of the sacraments (baptising and the breaking of the bread or Communion) are the means by the which the ascended King creates and extends his kingdom. (p. 536)

To Grudem (1994:864), this means, 'As the church proclaims the good news of the kingdom, people will come into the church and begin to experience the blessings of God's rule in their lives.' It is human beings who preach the gospel and administer the sacraments which means that, in this present age until the eschaton, the church expresses the presence, the operation and the power of the kingdom through its various Christ-centred activities. In the Bible, the manifestations of the kingdom were through God-driven human agency such as the human activity of the prophets, the apostles and the various ministerial activities of the church.

Although there are varying views on the relationship between the church and the kingdom of God, Pentecostal prophets are challenged to view their prophetic agency within the perspective of an ecclesiology that is submissive to the Lordship of Christ instead of the entrepreneurial model common among Pentecostal prophets. Although the Bible presents the church as an instrument of God's kingdom that witness to it, the two are recognised as distinct but related (Ladd 1993:103-117). Through the preaching of the gospel, Christians witness to the kingdom of God and it is not equivalent to building the kingdom of God, because it is God who builds his own kingdom. The caveat here is the danger of elevating or even equating our parochial churches with the kingdom of God and, in the process, legitimising the selfish human agendas of the prophets. For when the power of God's kingdom is impersonalised, the kingdom is vulnerable to commodification by the prophets and can be used to legitimise selfish human agendas. The kingdom of God is the exclusive work of God that challenges the impersonalisation and commodification of the kingdom by the Pentecostal prophets.

Further, for human agency to avoid impersonalising God and commodifying his kingdom, it must follow the leadership model of Christ as the Servant-King and reject the popular Pentecostal prophet's model of despotism, accumulation of wealth and self-aggrandisement. Biblical texts such as Isaiah 53, John 13:1-13 and Philippian 2:1-11 affirm Jesus as the King who exercised his rule and authority by service and not self-centred despotic lordship. Christ exhibited lordship modelled on servanthood, shunned the lordship of a master and, likewise, demanded his disciples to be servants and masters (Mk 10:42-45; Lk 22:24-26). Magezi (2015:7) reminds church leaders in Africa that, as King and Servant simultaneously, Jesus merged kingship and servanthood in a way that provides reference and example to all leaders. Christ presented a paradigm shift from autocratic oriented leadership to servant and accountable leadership within the kingdom of God. Therefore, African Pentecostal prophets are challenged to abandon their entrepreneurial model that impersonalises God's power and commodifies the gospel that, among many things, thrives on power and accumulation of wealth. Rather, they should adopt the paradigm modelled by the Servant King who sacrificially identifies with his people to serve them (Is 53), empowering them to be mature and passionate believers, and leading them to relate to God as a personal being and not an impersonal power. An essential foundation of Christ's servant-king leadership paradigm is its eschatological goal where God will demand an account of how one would have fulfilled their calling and reward his faithful servants (Mt 25:21).

\section{Conclusion}

The article attempted to critically analyse the understanding of the power of God's kingdom as expressed in the ministries and teachings of some Zimbabwean Pentecostal prophets. The article highlighted that the kingdom of God is of central attention to Pentecostal prophets in Zimbabwe. The prophets view themselves as special agents of the kingdom and seek to bring people into its realm. However, rather than treating the kingdom as a reality of the personal triune God, these Pentecostal prophets treat the power of the kingdom as an impersonal force that can be manipulated by human ingenuity. This leads the prophets to commodify the kingdom instead of revering it as the presence and manifestation of God's work. Therefore, Pentecostal prophets are challenged to view the kingdom of God from the perspective of the triune personal God and a sound biblically informed understanding of God's kingdom. Pentecostal prophets are further challenged to seriously consider the crippling effect of their faulty notions of God's kingdom on their followers. The prophets should be concerned that their impersonalisation of God leaves their followers unhealthily dependent on them (the prophets) instead of developing their own personal dependence on the God of the kingdom.

\section{Competing interests}

The author declares that he has no financial or personal relationship(s) which may have inappropriately influenced him in writing this article. 


\section{References}

Angel, U., 2013, God's get rich quick scheme: Secrets to the quickest way of getting rich God's way, Spirit Library, Dallas, TX.

Balcomb, A., 2007, 'Well healed and well-heeled: Pentecostals in the new South Africa - Their message, structures and modes of socio-political intervention', Missionalia 35(3), 30-42.

Bulawayo24News 2013, Prophet Uebert Angel reveals how much he's worth viewed 08 March 2018, from https://bulawayo24.com/index-id-news-sc religion-byo-37612.html

Bulla, F., 2015, Anointed mantles: A business gimmick, viewed 20 April 2018, from http://www.sundaymail.co.zw/anointed-mantles-a-business-gimmick/

Chaya, V, 2016, Magaya cucumbers raise eyebrows, viewed 22 March 2017, from https://www.dailynews.co.zw/articles/2016/11/28/magaya-cucumbers-raiseeyebrows

Chitando, E. \& Biri, K., 2016, 'Walter Magaya's Prophetic Healing and Deliverance (PHD) Ministries and Pentecostalism in Zimbabwe: A preliminary study with particular reference to ecumenism', Studia Historiae Ecclesiasticae 42(2), 72-85.

Chitando, E., Gunda, M.R. \& Kügler, J., 2013, Prophets, profits and the Bible in Zimbabwe: Festschrift for Aynos Masotcha Moyo, University of Bamberg, Bamberg.

Chitemba, B., 2017, Makandiwa sued for 'fake' prophecies, viewed 08 March 2018 from http://www.sundaymail.co.zw/makandiwa-sued-for-fake-prophecies/

De Gruchy, J.W., 1979, The Church struggle in South Africa, David Philip, Cape Town.

De Gruchy, J.W., 1995, Christianity and democracy: A theology for a just world order, David Philip, Cape Town.

Dunn, J.D.G., 2011, Jesus, Paul and the gospels, Wm. B. Eerdmans, Grand Rapids, MI.

Forbes Africa, 2014, The prophet of success, viewed 08 March 2018, from https:// www.forbesafrica.com/focus/2014/05/01/the-prophet-of-success/

Frame, J.M., 2002, The doctrine of God, P\&R, Phillipsburg, NJ.

Grudem, W.A., 1994, Systematic theology: An introduction to biblical doctrine, IVP Leicester.

Gunda, M.R. \& Machingura, F., 2013, 'The "Man of God": Understanding biblical influence on contemporary mega- church prophets in Zimbabwe', in E. Chitando, M.R. Gunda, \& J. Kügler (eds.), Prophets, profits and the Bible in Zimbabwe: Festschrift for Aynos Masotcha Moyo, pp. 15-28, University of Bamberg, Bamberg.

Guthrie, D., 1981, New Testament theology, IVP, Leicester.

Hellstern, M., 1989, 'The "Me Gospel": An examination of the historical roots of the prosperity emphasis within current charismatic theology', Fides et Historia 21 prospe

Horton, M., 2011, The Christian Faith: A systematic theology for pilgrims on the way, Zondervan, Grand Rapids, MI.

Kgatle, M.S., 2017, 'The unusual practices within some Neo-Pentecostal churches in South Africa: Reflections and recommendations', HTS Teologiese Studies/ Theological Studies 73(3), a4656. https://doi.org/10.4102/hts.v73i3.4656

Ladd, G.E., 1993, A theology of the New Testament, reviewed edn, W.B. Eerdmans, Grand Rapids, MI.

Ladd, G.E., 2001, 'Kingdom of Christ, God, Heaven', in W.A. Elwell (ed.), Evangelical dictionary of theology, pp. 657-661, Baker, Grand Rapids, MI.

Magaya, W., 2015a, Thy Kingdom come, viewed 28 January 2018, from http://magaya. hurukuros.com/2015/05/prophet-w-magaya-teaching-on-thy.html
Magaya, W., 2015b, Teaching on the kingdom of God, viewed 28 January 2018, from http://magaya.hurukuros.com/2015/11/teaching-on-kingdom-by-prophetmagaya.html

Magezi, V., 2015, 'God-image of Servant King as powerful but vulnerable and serving: Towards transforming African church leadership at an intersection of African kingship and biblical kingship to servant leadership', HTS Teologiese Studies/ Theological Studies 71(2), Art. \#2907, 9 pages. https://doi.org/10.4102/

Magezi, V. \& Banda, C., 2017, 'Competing with Christ? A critical Christological analysis of the reliance on Pentecostal prophets in Zimbabwe', In die Skriflig 51(2), a2273. https://doi.org/10.4102/ids.v51i2.2273

Magezi, V. \& Manzanga, P., 2016, 'Prosperity and health ministry as a coping mechanism in the poverty and suffering context of Zimbabwe: A pastora evaluation and response', In die Skriflig 50(1), a2076. https://doi.org/10.4102/ids. v50i1.2076

Mahohoma, T.C., 2017, 'A theological evaluation of God business: A case study of the Prophetic Healing and Deliverance Ministries of Zimbabwe', HTS Teologiese Studies/Theological Studies 73(2), a4529. https://doi.org/10.4102/hts.v73i2.4529

Makandiwa, E., 2013, Preaching on the kingdom of God, Part 3, viewed 30 March 2018, from https://www.youtube.com/watch?v=JQYMzAXecmk

Makandiwa, E., 2014, 'Jesus the greatest', The Family 2, 6-7.

Makandiwa, E., 2017, The kingdom of God. Part 2, viewed 27 January 2018, from https://www.youtube.com/watch?v=wzmHVDYpkjQ

Marshall, R., 1992, 'Pentecostalism in Southern Nigeria: An overview', in P. Gifford, (ed.), New dimensions in African Christianity. The Church in African Christianity: Innovative essays in Ecclesiology, pp. 7-32, AACC, Nairobi.

Marshall, R., 2009, Political spiritualties: The Pentecostal revolution in Nigeria, University of Chicago, Chicago, IL.

Maxwell, D., 2006, African gifts of the spirit: Pentecostalism \& the rise of a Zimbabwean transnational religious movement, Weaver, Harare.

Mbanje, P., 2015, Pastor defends 'anointed' condoms, viewed 22 March 2017, from https://www.newsday.co.zw/2015/12/04/pastor-defends-anointed-condoms/

Nehanda Radio, 2018, Prophet Uebert Angel wealth exposed, viewed 08 March 2018, from http://nehandaradio.com/2018/01/30/prophet-uebert-angel-wealthexposed/

Nemukuyu, D., 2014, Prophet Angel sued over Bentley, viewed 08 March 2018, from http://www.chronicle.co.zw/prophet-angel-sued-over-bentley/

Nürnberger, K., 1994, 'The task of the church concerning the economy in a postapartheid South Africa', Missionalia 22(2), 118-146.

Nyamiti, C., 1997, 'The doctrine of God', in J. Parratt (ed.), A reader in African Christian Theology, pp. 57-64, SPCK, London.

Oyakhilome, C., 2007, Recreating your world, LoveWorld Pub, Folkestone.

Resane, K.T., 2017, “'And they shall make you eat grass like oxen” (Daniel 4: 24): Reflections on recent practices in some New Charismatic Churches', Pharos Journal of Theology 98, 1-17.

Rukwati, T., 2012, Prophets mustn't be questioned, viewed 17 March 2017, from http://www.herald.co.zw/prophets-mustnt-be-questioned/

Seccombe, D., 2002, The king of God's kingdom: A solution to the puzzle of Jesus, Paternoster, Milton Keynes.

The Family, 2014a, 'Soul winning crusades filled with miracles, signs and wonders', The Family 2, 28-33.

The Family, 2014b, 'Hundreds delivered from sleeping disorder', The Family 2, 10-11.

The Sunday Mail, 2017, Makandiwa in controversial video, viewed 24 July 2017, from http://www.sundaymail.co.zw/makandiwa-in-controversial-video/ 